\title{
EXTRACTION OF BIO OIL FROM FUCUS VESICULOSUS AND CLADOPHORA GLOMERATA ALGAL SPECIES
}

\author{
Zahraa N. Hussain ${ }^{1}$ and Ali A. Jazie ${ }^{2}$ \\ 1 Chemical Engineering Department - Faculty of Engineering - University of Al- \\ Qadisiyah-Iraq. Email: Zahraanzzal1992@gmail.com \\ 2 Assist. Prof .. Dr. Ali Abd Al-Hussein Jazie, Chemical Engineering Department - \\ Faculty of Engineering - University of Al-Qadisiyah-Iraq. Email: Ali.Jazie@qu.edu.iq \\ HTTPS://DOI.ORG/10.30572/2018/KJE/120403
}

\begin{abstract}
One of the difficulties of using algae produces of biofuels the development of an active and economically feasible process for oil extraction from these unicellular algae. Algae have a high fat content. In this study two types of algae were used, Fucus vesiculosus and Cladophora glomerata moss algae. Where these algae are collected from swamps and marine waters and left under sunlight to dry for a period of three days. A comparative study was conducted to extract fats from algae using Soxhlet where organic solvents were used in the separation process such as methanol and ethyl acetate. Methanol is used more often because it is cheap and has chemical and physical characteristic. We use the ethyl acetate to prove that not good for extraction. The extraction processes by using organic solvents in the Soxhlet device have shown promising results. Different ratios of solvent to algal weight were tested. The properties of bio oil also were characterized using FTIR and GC-MS spectroscopy methods. The maximum yield of bio oil obtained using C.glomerata and F.vesiculosus were 0.134 and 0.195 using methanol solvent.
\end{abstract}

KEYWORDS: Fucus vesiculosus, Cladophora glomerata, liped extraction, algae, bioFUEL. 


\section{INTRODUCTION}

Algae is a so promising raw material for producing oils for use like a fuel (Pandey et al., 2018) In addition, it does not require high soil use and does not need fresh water and can grow in sea water or wastewater, and grow faster in a very short amount of time, and the generated oil does not represent a threat to food security, it can reduce the impact of climate change and the resulting global warming due to the large number of greenhouse gases generated from fuel due to the low carbon emission from algae fuel (Bwapwa, Anandraj and Trois, 2017). Nonetheless, It is important to note the cost of generating algae biofuels cannot currently be compared to the cost of fossil fuels (Sun et al., 2011). The economic feasibility production of biofuel from algal seems to rely on the biomass being used multiply (Sun et al., 2011). Algae have many beneficial characteristics which authorize it for used in Different systems. Such characteristics include many species of algae with premium protein amount, Elevated lipid standard and carbohydrate. Usage ranges from nutrients in nutrition to Bio fuelling, and in Phytoremedying. The rapid algae growth Make it beneficial to both nutrients and biofuel. algae in photosynthesis operations it is using carbon dioxide advent from massive scale manufactures, which leads to protecting part of the environment from pollution, in addition to that it functions as a vital adsorbent to clean the streams of used polluted water (El Sikaily et al., 2006). Microalgae are capable of synthesizing and accumulating the triacylglycerol under stress conditions. Triacylglycerol's (TAGs) are present as storage lipids in the cell (Gualtieri, 2006). The most common fatty acids in algae are stearic (18:0), palmitic (16:0), oleic (18:1), linoleic (18:3), linoleic (18:2) and some species may also have docosahexaenoic acid (22:6) and eicosapentaenoic acid (20:5) (Islam et al., 2013). Algae lipids are usually composed of fatty acid esterified glycerol, sugars or bases containing 12 to 24 carbons, inclusive medium chain (C10-C14), long chain (C16-18), and long chain of fatty acids (C20-C24) (Shahzad et al., 2010). In the present work, a comparison study was conducted for optimizing the content of oil in two types of algae. The suitability of solvent was checked. Also, the properties and composition of the algal oils was tested.

The extraction of algal oil is one more challenge which is most readily about the Engineering part. Extraction may be classified in general for three processes: electrical, mechanical, and chemical. The mechanical compress usually requires drying the algae, which consume large power. Whereas the utilize of chemical solvent causes health problems (Leite, Abdelaziz and Hallenbeck, 2013). In electrical process, pulsate electric range is Removal technology which uses electrical current to fractional of cell wall for algae (Nafis et al., 2015). Nevertheless, solvent chemical solvent extraction is more commonly using because it is simple to operate 
(Pradana et al., 2017a). The traditional method used to extraction oil from algae is the extraction process of organic solvents (Mercer and Armenta, 2011). The process of reducing the cost per kilogram of biofuels produced from algae is very important, and the recovery process can be the key to reducing the total cost (Jazie, Alshebaney and Abed, 2019). Various techniques have been proposed for the extraction of lipids, the most common is the Soxhlet (Soxhlet, 1879). Solvents include; chloroform, methanol and hexane. While this processes are so successful in extraction overall lipids, they may be considered dangerous for a human health, but hexane can have neurotoxic impacts. In addition, chloroform a carcinogenic halogenated solvent which can contribute to the formation of phosgene and hydrochloric acid via its prolonged storage. Consequently, the use of this solvent in extraction lipids is strictly prohibited (Nelson, 1993), (Probst et al., 2017). Green oil extraction with hexane in the laboratory is commonly carry out by the Soxhlet extraction at $\left(70^{\circ} \mathrm{C}\right)$ for $(18 \mathrm{~h})$ (Demirbaş, 2008). That long time heating period and extraction is inconvenient by using hexane solvent (Classics Bligh and Dyer, 1959). Although methanol, ethanol, propanol, and other higher alcohols can be used in this process, methanol is used more often because it is cheap and has chemical and physical characteristic (Ma and Hanna, 1999). The method of extracting organic solvents depends on the affinity of the solvent-solvent, as it requires different types of reactions to achieve the highest productivity of extraction. Non-polar organic solvents work to disrupt the hydrophobic reactions (van der Waals forces) among non-polar / neutral fats while polar organic solvents crack down the hydrogen bonds among polar fats (Johnson and Lusas, 1983). A successful solvent to lipid extraction must have the following advantages: strong affinity for lipids, lower boiling point, lower toxicity and reasonable restore and reuse susceptibility (Mercer and Armenta, 2011).

In the present work, two types of algal species (Fucus vesiculosus and Cladophora glomerata) were chosen for bio oil production through the Soxhlet extraction method using methanol and ethyl acetate as solvents. Different ratios of solvent to algal weight were tested. The properties of bio oil also were characterized using FTIR and GC-MS spectroscopy methods.

\section{EXPERIMENTAL WORK}

\subsection{Material and apparatus used}

Ttypes of algae Fucus vesiculosus (F. vesiculosus) and Cladophora glomerata (C. glomerata) were used in this research. The first one was bought from herbal stores and the other type was collected from water pools from Al-Qadisiyah University. Methanol: $(\mathrm{CH} 3 \mathrm{OH}),(\mathrm{M} . \mathrm{Wt}=32.04)$ and purity (99.8\%), (Fisher Scientific, India), ethyl acetate: (C4H8O2) and purity (99.5), (Fisher 
Scientific, India). Soxhlet extraction device used to extract algae oil, D.K. Scientific industries, India MART, rotary evaporator device used to vaporize the solvent to separate it from alga oil.

\subsection{Experimental set up}

Initially algae are collected, removed from impurities, and dried under sunlight for 3 days to remove moisture. Then the algae were ground with a grinding machine pestle to obtain precise algae size ranges between $(35 \mu \mathrm{m}$ and $90 \mu \mathrm{m}$ ). Different weights were taken from the microalgae and placed in the filter paper. The solid material containing the compound is put in the major room of Soxhlet apparatus. This process was performed using the polar solvent methanol alcohol or ethyl acetate where 200 milliliters of methanol or ethyl acetate were placed in the beaker at the bottom of the Soxhlet extractor apparatus. At the top of the device, the capacitor is placed. To re-dissolve must be solvent is heated. Vapor of solvent moves in the arm of distillation, then stream into the chambers that contain the extracted solid this process shown in (Fig. 1). The capacitor assures that every vapor of solvent is cooled as it dropping in to the chamber that contains solid material. Chamber that contains solid materials is slow filled with hot solvent. These were allowed the warm solvent to resolve some of the desired solid material. When chamber of Soxhlet is almost filled, is taken off the liquid from the chambers by the side siphon arm then solvent returns to distillation flask once more. This process is repeated several times and lasts for several hours or several days.

Through every cycle a fraction the compound is dissolved in solvent. Next several cycles, compound is centered in flask of distillation. Characteristic of that system the warm solvent can be passed through the sample more than once, in this process a fixed amount of the solvent can be used and recycled. 


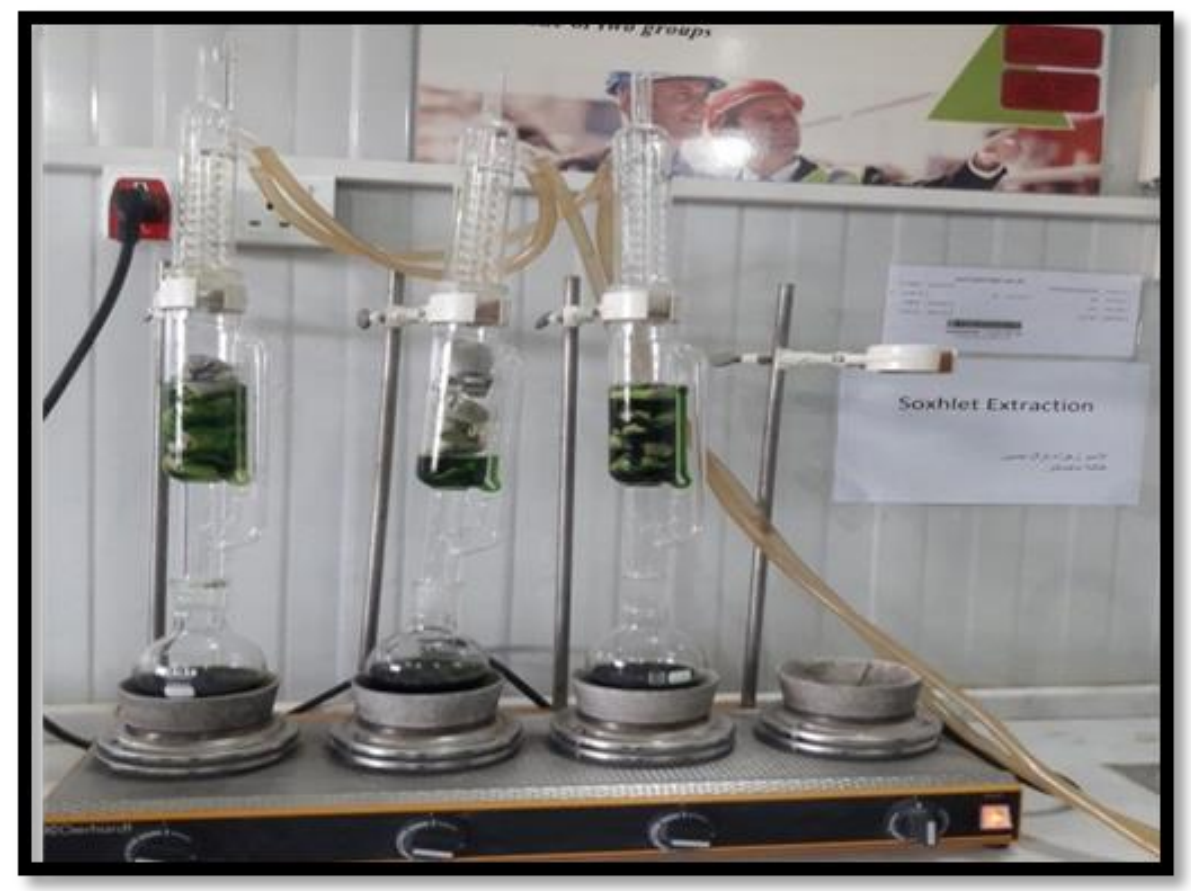

Fig. 1. Photographic pictures of Soxhlet extraction.

The solvent is removed after the extraction process by using the rotary evaporator device and the extracted oil remain. The insoluble solid part remains in the tube of extraction device and is usually disposed of a show in (Fig. 2).

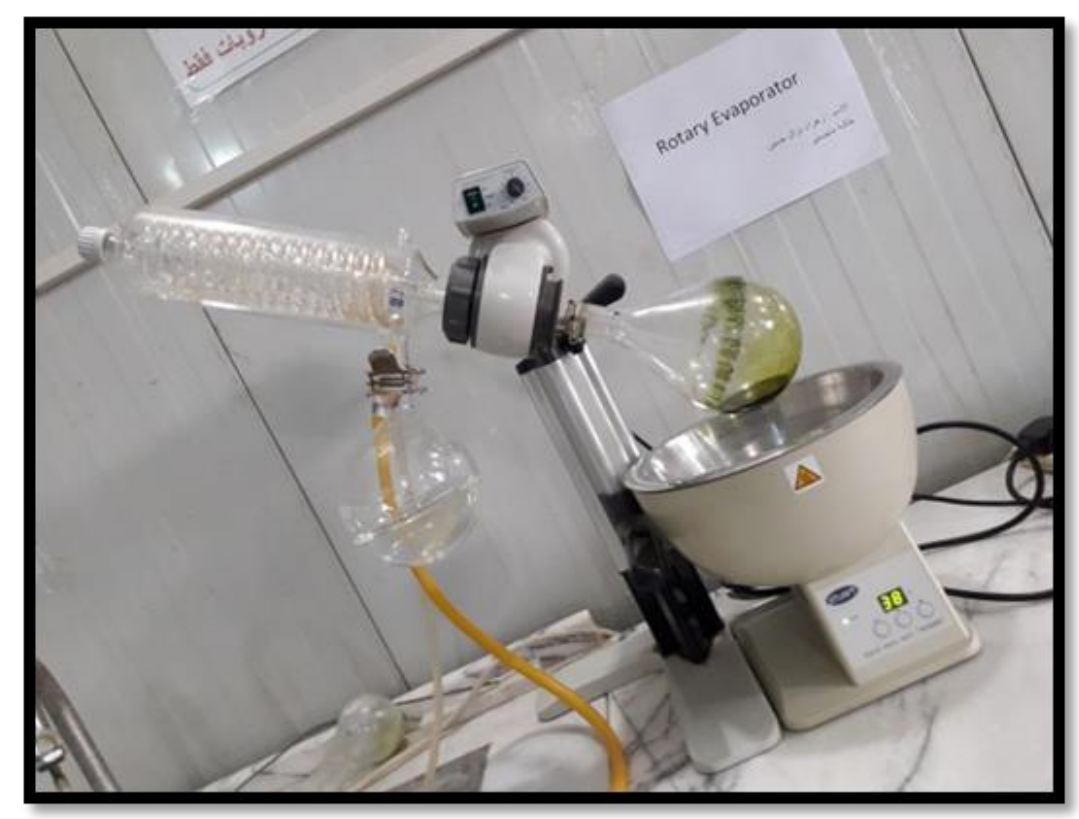

Fig. 2. Photographic pictures of Rotary Evaporator. 
Dry oil yield of extracted $\left(W_{o i l-d r y}\right)$ was determined from calculating the amount of dry algae by use Eq.1 fat specimen extracted of algae were analysis to the fatty acid Profiling (Pradana et al., 2017b).

Yield $=\frac{W_{\text {oil }- \text { dry }}}{\left.W_{\text {m.a-dry }}\right)} \times 100 \%$

$W_{m . a-d r y}=$ Weight of algae dry used

$W_{o i l-d r y}=$ The yield of dry oil derived from dry algae calculated

The results obtained from the extraction processes are shown in Table 1.

Table 1. Solvent volumes and algae used in each extraction system.

\begin{tabular}{ccccc}
\hline $\begin{array}{c}\text { Soxhlet } \\
\text { Extraction }\end{array}$ & Algae type & Solvent & Time & $\begin{array}{c}\text { Yield, for (g dry } \\
\text { algal oil/g dry algae) }\end{array}$ \\
\hline System1 & 160g of C.glomerata & $600 \mathrm{ml}$ Methanol & 18 hours & 0.149 \\
System2 & 160g of C.glomerata & $600 \mathrm{ml}$ Methanol & 19 hours & 0.195 \\
System3 & 160g of F.vesiculosus & $600 \mathrm{ml} \mathrm{Methanol}$ & 18 hours & 0.1778 \\
System4 & 160g of F.vesiculosus & $600 \mathrm{ml}$ Methanol & 18 houres & 0.1798 \\
System5 & 160g of F.vesiculosus & $600 \mathrm{ml}$ Methanol & 19 houres & 0.1998 \\
System6 & 160g of F.vesiculosus & $900 \mathrm{ml}$ Ethyl -acetate & 24 houres & 0.134 \\
\hline
\end{tabular}

Algae of C.glomerata offers the higher yield of algae oil 0.195 dry algal oil/g algae by using methanol as a solvent and the type's algae of F. vesiculosus show the higher yield 0.1998 after extraction by using methanol solvent. But the lowest yield when we use ethyl acetate as a solvent. So, the extraction process performed proved that the use of methanol is preferable to the use of ethyl acetate.

The properties of bio oil were characterized using FTIR and GC-MS spectroscopy methods. Fourier transform medium range infrared spectroscopy (FTIR) was used to set a percentage of a raw materials transformed into biofuels in various reactions. Band intensity was measured for the content measurement $(\mathbf{C}=\mathbf{0})$ by using an analytical curve. The test applied at Al-Qadisiyah University at the college of Engineering by using FTIR using Bruker, Tensor II, Germany and 
the resolution of this device used within the $1 \mathbf{~ c m}^{-1}$ within the spectrum range 4000-400 cm1.

Liquid product formulations were evaluated with by using Gas chromatograph mass spectrometer (GC-MS) (Agilent 6890N series GC with a 5973 N Inert MS detector and 7683 Injector). Separation of (GC-MS) was performed by using the (DB-5) poetical column $(30 \mathrm{~m} \times 0.25 \mathrm{~mm} \times 0.25 \mu \mathrm{m})$ a ready sample $(1 \mu \mathrm{L})$ was injected in to the injection executor at temperature $\left(250^{\circ} \mathrm{C}\right)$ in the Split mode for $(100: 1)$. Was used a helium gas with high pureness (He) $(99.999 \%)$ as carrier in a column with constant flow rate (1.2 $\mathrm{ml} / \mathrm{min})$.Temperature of Column was set at $\left(40{ }^{\circ} \mathrm{C}\right)$ for $(5 \mathrm{~min})$ prior being increased for $\left(100{ }^{\circ} \mathrm{C}\right.$ at $\left.20^{\circ} \mathrm{C} / \mathrm{min}\right)$ therefore to $\left(250{ }^{\circ} \mathrm{C}\right.$ at $\left.5^{\circ} \mathrm{C} / \mathrm{min}\right)$.

\section{RESULT AND DISCUSSION}

\subsection{Specification of biomass of algae and oil extracted}

FTIR Study for algal oil taken from F. vesiculosus and C. glomerata biomass in (Fig. 3) and (Fig. 4) oil of algae created leading $(\mathbf{C}-\mathbf{H})$ extend at (3604-2994 $\left.\mathbf{c m}^{\mathbf{- 1}}\right)$, shaking of curvature $\mathbf{C H}_{2}$ at $\left(1256.12 \mathbf{c m}^{-\mathbf{1}}\right)$ and $\left(\mathbf{C H}_{3}\right)$ curvature at a $\left(1368.12 \mathbf{c m}^{-\mathbf{1}}\right)$. outstanding heteroatom operation was observed at area $\left(1600.96 \mathbf{c m}^{-1}\right)$, and $\left(1101.49 \mathbf{c m}^{-1}\right)$. A strong $(\mathbf{C}=\mathbf{0})$ stretch was gained at $\left(1600.96 \mathbf{c m}^{-1}\right)$. Algae oil series was distinguished from the other a biologically speaking earned oils like they created a strong alkane climax (3600-2990 $\mathbf{c m}^{\mathbf{- 1}}$ ), as well exhibited weak heteroatom linked peaks and linked to a higher hydrocarbons. $(\mathbf{C}=\mathbf{0})$ : Carbonyl component it is about esters in a spectral .So, it display spectra to the peak $\left(\mathbf{1 6 0 0 . 9 6} \mathbf{~ c m}^{-1}\right)$. (C-O-C ethers): That spectrum reveals an extend band $\left(1300\right.$ and $\left.1100 \mathrm{~cm}^{-1}\right)$; $(\mathbf{C}-\mathbf{H})$ the spectrum that shapes this stretch, that depict the advantage of the absorption bands. Show in FTIR spectra, a spectra among (2925.71 $\mathbf{2 8 5 4 . 7 9} \mathbf{c m}^{-1}$ ) symbolize the symmetrical and no symmetrical style of a methyl groups,

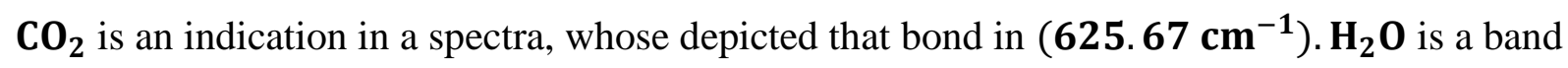
from adsorption, which could be seen in a spectral range of $\left(\mathbf{1 7 0 0}\right.$ to $\left.1250 \mathbf{~ m}^{-1}\right)$ A. Esmaeili1 et al. spotted a strong peak in $\left(\mathbf{1 6 5 5} \mathbf{c m}^{-\mathbf{1}}\right)$ were recognized to a $(\mathbf{C}=\mathbf{0})$ stretching shaking (Esmaeili and Beni, 2018), (Esmaeili and Beni, 2015). 


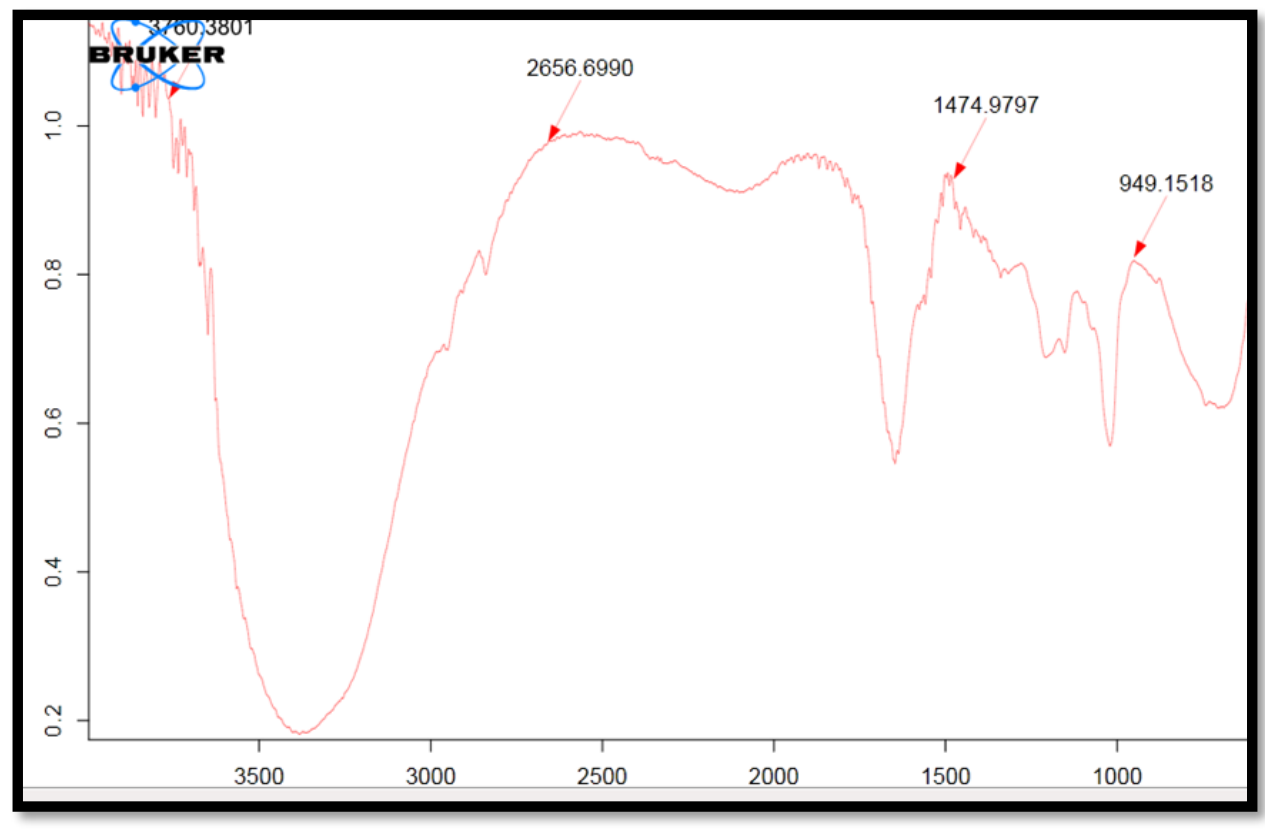

Wavenumbers $\left(\mathrm{cm}^{-1}\right)$

Fig. 3. FTIR for algal oil from $F$. vesiculosus.

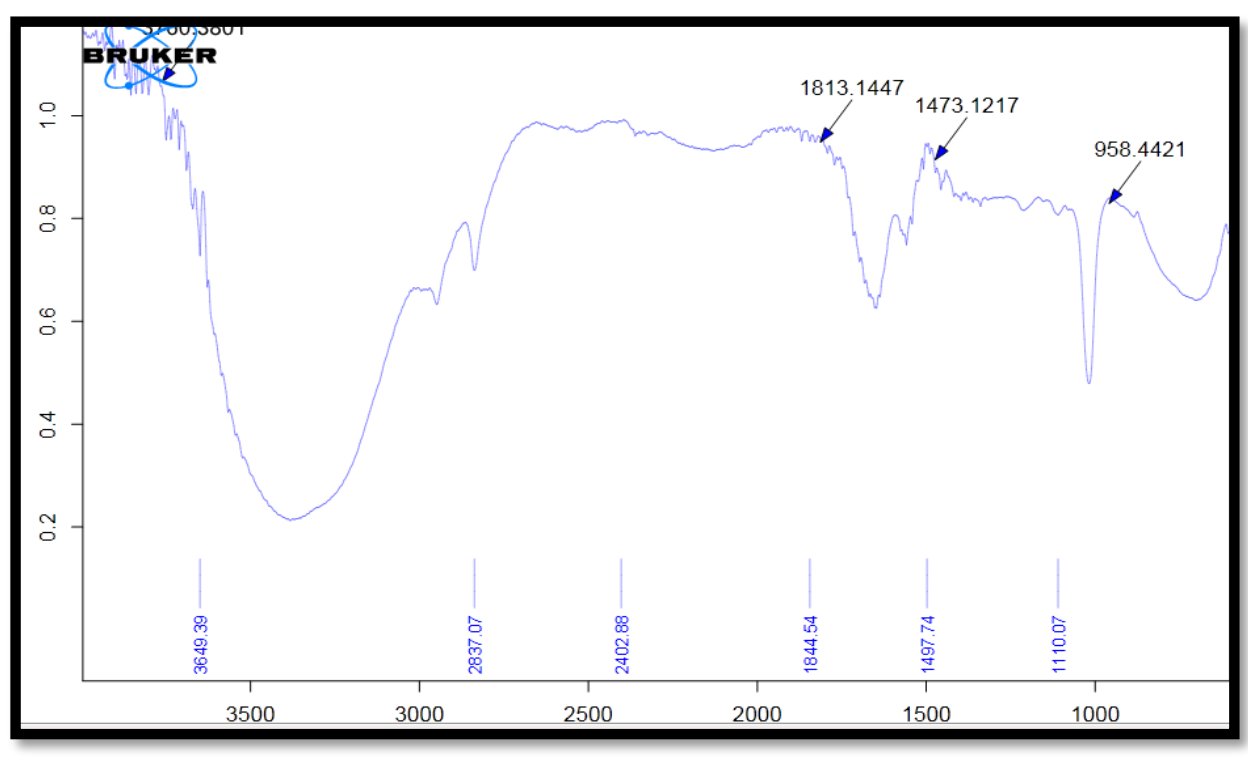

$$
\text { Wavenumbers }\left(\mathrm{cm}^{-1}\right)
$$

Fig. 4. FTIR for algal oil from C. glomerata.

GC - MS analyzes were performed in order to find out the hydrocarbons present in algae oil different classes of hydrocarbons were obtained for both algae (F. vesiculosus) and algae (C. glomerata) in the Tables 2 and 3. Different classes of hydrocarbons were obtained which include aromatic amines, nitriles, alkenes and carbohydrates. The most saturated fatty acids (SFAs) in the genus Fucus are palmitic followed through myristic acids (Kim et al., 1996). 
While the most saturated fatty acids (SFAs) in C. glomerata are myristic acid and palmitic acid (Marycz et al., 2017).

Table 2. GC-MS analysis for oil of algae F. vesiculosus.

\begin{tabular}{|c|c|c|c|c|c|c|c|}
\hline No. & $\begin{array}{c}\text { Molecular } \\
\text { formula }\end{array}$ & $\begin{array}{c}\text { Peak } \\
\text { Area \% }\end{array}$ & $\begin{array}{c}\text { Reaction } \\
\text { Time }\end{array}$ & No. & $\begin{array}{c}\text { Molecular } \\
\text { formula }\end{array}$ & $\begin{array}{c}\text { Peak } \\
\text { Area \% }\end{array}$ & $\begin{array}{c}\text { Reaction } \\
\text { Time }\end{array}$ \\
\hline 1 & $\mathrm{C}_{5} \mathrm{H}_{11} \mathrm{NO}$ & 0.330 & 6.05 & 16 & $\mathrm{C}_{16} \mathrm{H}_{22} \mathrm{O}_{4}$ & 0.203 & 19.47 \\
\hline 2 & $\mathrm{C}_{4} \mathrm{H}_{9} \mathrm{NO}$ & 0.205 & 6.62 & 17 & $\mathrm{C}_{16} \mathrm{H}_{22} \mathrm{O}_{4}$ & 12.302 & 19.52 \\
\hline 3 & $\mathrm{C}_{6} \mathrm{H}_{13} \mathrm{NO}$ & 1.318 & 7.20 & 18 & $\mathrm{C}_{18} \mathrm{H}_{36}$ & 1.710 & 19.86 \\
\hline 4 & $\mathrm{C}_{4} \mathrm{H}_{9} \mathrm{NO}$ & 1.276 & 7.38 & 19 & $\mathrm{C}_{22} \mathrm{H}_{44} \mathrm{O}_{2}$ & 0.506 & 19.98 \\
\hline 5 & $\mathrm{C}_{10} \mathrm{H}_{20} \mathrm{O}_{2}$ & 0.221 & 9.48 & 20 & $\mathrm{C}_{19} \mathrm{H}_{38} \mathrm{O}$ & 0.333 & 20.64 \\
\hline 6 & $\mathrm{C}_{14} \mathrm{H}_{22}$ & 0.163 & 11.06 & 21 & $\mathrm{C}_{19} \mathrm{H}_{40} \mathrm{O}$ & 1.690 & 20.80 \\
\hline 7 & $\mathrm{C}_{14} \mathrm{H}_{22} \mathrm{O}$ & 0.192 & 14.54 & 22 & $\mathrm{C}_{19} \mathrm{H}_{36} \mathrm{O}_{2}$ & 0.299 & 20.87 \\
\hline 8 & $\mathrm{C}_{12} \mathrm{H}_{14} \mathrm{O}_{4}$ & 0.144 & 15.48 & 23 & $\mathrm{C}_{19} \mathrm{H}_{36} \mathrm{O}_{2}$ & 0.219 & 20.93 \\
\hline 9 & $\mathrm{C}_{16} \mathrm{H}_{32}$ & 0.828 & 15.55 & 24 & $\mathrm{C}_{18} \mathrm{H}_{36} \mathrm{O}$ & 0.279 & 20.98 \\
\hline 10 & $\mathrm{C}_{15} \mathrm{H}_{30} \mathrm{O}$ & 0.361 & 16.48 & 25 & $\mathrm{C}_{19} \mathrm{H}_{38} \mathrm{O}_{2}$ & 0.291 & 21.11 \\
\hline 11 & $\mathrm{C}_{21} \mathrm{H}_{44}$ & 0.158 & 16.79 & 26 & $\mathrm{C}_{15} \mathrm{H}_{28} \mathrm{O}_{2}$ & 0.215 & 21.22 \\
\hline 12 & $\mathrm{C}_{18} \mathrm{H}_{36}$ & 1.300 & 17.82 & 27 & $\mathrm{C}_{18} \mathrm{H}_{36} \mathrm{O}_{2}$ & 0.550 & 21.43 \\
\hline 13 & $\mathrm{C}_{16} \mathrm{H}_{22} \mathrm{O}_{4}$ & 0.325 & 18.54 & 28 & $\mathrm{C}_{14} \mathrm{H}_{28}$ & 0.162 & 21.68 \\
\hline 14 & $\mathrm{C}_{18} \mathrm{H}_{36} \mathrm{O}$ & 0.845 & 18.66 & 29 & $\mathrm{C}_{22} \mathrm{H}_{46} \mathrm{O}$ & 1.290 & 21.73 \\
\hline 15 & $\mathrm{C}_{17} \mathrm{H}_{34} \mathrm{O}_{2}$ & 4.316 & 19.17 & 30 & $\mathrm{C}_{20} \mathrm{H}_{40} \mathrm{O}_{2}$ & 0.255 & 21.84 \\
\hline
\end{tabular}

\subsection{Algae properties}

The properties of the resulting oil were tested in the research and development center in Table 4.

\subsubsection{Specific Gravity}

The specific gravity of the biofuel was measured as specified in ASTM D4052. The hydrometer was used to measure the specific gravity by filling a graduated cylinder with biofuel and drop the hydrometer into the biofuel. The point at which the hydrometer floats is the measurement of specific gravity (Demirbas and Balat, 2006).

\subsubsection{Kinematic Viscosity}

The kinematic viscosity was determined at $40{ }^{\circ} \mathrm{C}$, using a Redwood viscometer No. 1 as specified in ASTM D445 (Balat, 2011). 
Table 3. GC-MS analysis for oil of algae C. glomerata.

\begin{tabular}{cccccccc}
\hline No. & $\begin{array}{c}\text { Molecular } \\
\text { formula }\end{array}$ & $\begin{array}{c}\text { Peak } \\
\text { Area \% }\end{array}$ & $\begin{array}{c}\text { Reaction } \\
\text { Time }\end{array}$ & $\begin{array}{c}\text { No. } \\
\text { Molecular } \\
\text { formula }\end{array}$ & $\begin{array}{c}\text { Peak } \\
\text { Area \% }\end{array}$ & $\begin{array}{c}\text { Reaction } \\
\text { Time }\end{array}$ \\
\hline 1 & $C_{5} \mathrm{H}_{11} \mathrm{NO}$ & 0.063 & 6.05 & 16 & $\mathrm{C}_{16} \mathrm{H}_{22} \mathrm{O}_{4}$ & 0.035 & 19.47 \\
2 & $\mathrm{C}_{4} \mathrm{H}_{9} \mathrm{NO}$ & 0.008 & 6.62 & 17 & $\mathrm{C}_{16} \mathrm{H}_{22} \mathrm{O}_{4}$ & 2.767 & 19.52 \\
3 & $\mathrm{C}_{6} \mathrm{H}_{13} \mathrm{NO}$ & 0.295 & 7.20 & 18 & $\mathrm{C}_{18} \mathrm{H}_{36}$ & 0.384 & 19.86 \\
4 & $\mathrm{C}_{4} \mathrm{H}_{9} \mathrm{NO}$ & 0.289 & 7.38 & 19 & $\mathrm{C}_{22} \mathrm{H}_{44} \mathrm{O}_{2}$ & 0.113 & 19.98 \\
5 & $\mathrm{C}_{10} \mathrm{H}_{20} \mathrm{O}_{2}$ & 0.017 & 9.48 & 20 & $\mathrm{C}_{19} \mathrm{H}_{38} \mathrm{O}$ & 0.041 & 20.64 \\
6 & $\mathrm{C}_{14} \mathrm{H}_{22}$ & 0.002 & 11.06 & 21 & $\mathrm{C}_{19} \mathrm{H}_{40} \mathrm{O}$ & 0.280 & 20.80 \\
7 & $\mathrm{C}_{14} \mathrm{H}_{22} \mathrm{O}$ & 0.043 & 14.54 & 22 & $\mathrm{C}_{19} \mathrm{H}_{36} \mathrm{O}_{2}$ & 0.068 & 20.87 \\
8 & $\mathrm{C}_{12} \mathrm{H}_{14} \mathrm{O}_{4}$ & $N \mathrm{ND}$ & 15.48 & 23 & $\mathrm{C}_{19} \mathrm{H}_{36} \mathrm{O}_{2}$ & 0.040 & 20.93 \\
9 & $\mathrm{C}_{16} \mathrm{H}_{32}$ & 0.187 & 15.55 & 24 & $\mathrm{C}_{18} \mathrm{H}_{36} \mathrm{O}$ & 0.057 & 20.98 \\
10 & $\mathrm{C}_{15} \mathrm{H}_{30} \mathrm{O}$ & 0.072 & 16.48 & 25 & $\mathrm{C}_{19} \mathrm{H}_{38} \mathrm{O}_{2}$ & 0.053 & 21.11 \\
11 & $\mathrm{C}_{21} \mathrm{H}_{44}$ & 0.036 & 16.79 & 26 & $\mathrm{C}_{15} \mathrm{H}_{28} \mathrm{O}_{2}$ & 0.049 & 21.22 \\
12 & $\mathrm{C}_{18} \mathrm{H}_{36}$ & 0.293 & 17.82 & 27 & $\mathrm{C}_{18} \mathrm{H}_{36} \mathrm{O}_{2}$ & 0.124 & 21.43 \\
13 & $\mathrm{C}_{16} \mathrm{H}_{22} \mathrm{O}_{4}$ & 0.074 & 18.54 & 28 & $\mathrm{C}_{14} \mathrm{H}_{28}$ & 0.034 & 21.68 \\
14 & $\mathrm{C}_{18} \mathrm{H}_{36} \mathrm{O}$ & 0.190 & 18.66 & 29 & $\mathrm{C}_{22} \mathrm{H}_{46} \mathrm{O}$ & 0.289 & 21.73 \\
15 & $\mathrm{C}_{17} \mathrm{H}_{34} \mathrm{O}_{2}$ & 0.971 & 19.17 & 30 & $\mathrm{C}_{20} \mathrm{H}_{40} \mathrm{O}_{2}$ & 0.056 & 21.84 \\
\hline & & & & & & \\
\hline
\end{tabular}

\subsubsection{Calorific Value}

The calorific value was calculated by weighing accurately one gram of the sample in the crucible of the calorimeter. Distilled water of $1750 \mathrm{ml}$ was poured into the calorimeter vessel. The bomb was re-assembled and charged with oxygen from a cylinder to a pressure of $25 \mathrm{psig}$. The sample was ignited and the change in temperature at equal interval of time was recorded. Finally, calculating the calorific value using a suitable equation as specified in IP12/63T (Balat, 2011).

\subsubsection{Cloud and Pour Points}

The cloud point is the temperature at which crystals first start to form in the sample when it is cooled. The pour point is a lowest of a temperature at which a biofuel is still pour from a container. 


\subsubsection{Flash Point}

The flash point was determined by Cleveland open cup method as specified in ASTM D92-53. A sample is contained in the open beaker that is heated, and at intermittent intervals a flame is brought over the surface. A flash point of the sample is a lowest temperature that which will flammable vapor is sufficient to ignite when an ignition source is used (Murugesan, Umarani, Subramanian, et al., 2009).

\subsubsection{Acid Value}

The (ASTM D664) measures an amount of the $\mathrm{KOH}$ that added through voltage calibration. Acid value is expressed like a mass of potassium hydroxide $(\mathrm{KOH})$ in a milligrams wanted to determine acids in a one gram of the sample (Murugesan, Umarani, Chinnusamy, et al., 2009).

\subsubsection{Cetane Number}

The Cetane number was estimated from the index of Cetane. A cetane number is calculated with the equation which takes into regard the fuel's gravity and the temperature of mid-boiling as specified in (ASTM D976) (Dabelstein et al., 2000).

Table 4. Properties of the oils of algae produced in the present study.

\begin{tabular}{ccc}
\hline Properties & Cladophora glomerata oil & Fucus vesiculosus oil \\
\hline Specific gravity & $0.887 \pm 0.02$ & 0.82 \\
Kinematic viscosity at & 3.8 & 2.4 \\
$40^{\circ} \mathrm{C}\left(\mathrm{mm}^{2} / \mathrm{sec}\right)$ & & \\
Cloud point $\left({ }^{\circ} \mathrm{C}\right)$ & 13 & 10 \\
Calorific value & 33.6 & 29.3 \\
Pour point $\left({ }^{\circ} \mathrm{C}\right)$ & -16 & $5-8$ \\
Flash point $\left({ }^{\circ} \mathrm{C}\right)$ & $108 \pm 0.12$ & 110 \\
Acid Value & $1.24 \pm 0.13$ & 1.9 \\
Cetane Number & 39.7 & +7 \\
\hline
\end{tabular}

\section{CONCLUSION}

Algae based fuels may be one of the most prominent ways to bio fuel It appears algae can technically be advantageous for an effective bio- fuel production compared bio fuel from other oil crops. Algae biomass have the ability to grow faster, they do not constitute a threat for food crops, they do not need excessive land to grow, they are not a threat for water resources and their crude bio-oil is very similar to petroleum crude oil in terms of carbon chains. Algae of 
C.glomerata offers the higher yield of dry algae oil is (0.195) dry algal oil/g algae and the type's algae of F. vesiculosus show the higher yield at (0.1998) after extraction. But the lowest yield when we use ethyl acetate as a solvent. So, the extraction process performed proved that the use of methanol is preferable to the use of ethyl acetate.

In addition to the moisture content of the biomass from algae must be reduced before the oil extraction process can take place, so when using dry biomass it produces a higher percentage of fat than using the biomass, which is wet. The amount of oils produced from the biomass depends on the type of algae used.

\section{REFERENCES}

Balat, M. (2011) 'Production of bioethanol from lignocellulosic materials via the biochemical pathway: a review', Energy conversion and management. Elsevier, 52(2), pp. 858-875.

Bwapwa, J. K., Anandraj, A. and Trois, C. (2017) 'Possibilities for conversion of microalgae oil into aviation fuel: A review', Renewable and Sustainable Energy Reviews. Elsevier Ltd, 80(May), pp. 1345-1354. doi: 10.1016/j.rser.2017.05.224.

Classics Bligh, E. G. and Dyer, W. J. (1959) 'A rapid method of total lipid extraction and purification', Can. J. Biochem. Physiol, 37, pp. 911-917.

Dabelstein, W. et al. (2000) 'Automotive fuels', Ullmann's Encyclopedia of Industrial Chemistry. Wiley Online Library, pp. 1-41.

Demirbaş, A. (2008) 'Production of biodiesel from algae oils', Energy Sources, Part A: Recovery, Utilization, and Environmental Effects. Taylor \& Francis, 31(2), pp. 163-168.

Demirbas, M. F. and Balat, M. (2006) 'Recent advances on the production and utilization trends of bio-fuels: a global perspective', Energy Conversion and Management. Elsevier, 47(15-16), pp. 2371-2381.

Esmaeili, A. and Beni, A. A. (2015) 'Biosorption of nickel and cobalt from plant effluent by Sargassumglaucescens nanoparticles at new membrane reactor', International Journal of Environmental Science and Technology. Springer, 12(6), pp. 2055-2064.

Esmaeili, A. and Beni, A. A. (2018) 'Optimization and design of a continuous biosorption process using brown algae and chitosan/PVA nano-fiber membrane for removal of nickel by a new biosorbent', International Journal of Environmental Science and Technology. Springer, 15(4), pp. 765-778.

Gualtieri, P. (2006) Algae: anatomy, biochemistry, and biotechnology. Taylor \& Francis,. 
Islam, M. A. et al. (2013) 'Microalgal species selection for biodiesel production based on fuel properties derived from fatty acid profiles', Energies. Multidisciplinary Digital Publishing Institute, 6(11), pp. 5676-5702.

Jazie, A. A., Alshebaney, E. J. and Abed, S. A. (2019) 'In-Situ Dodecylbenzenesulfonic acidCatalyzed Transesterification of Micro Algae Chlorella Sp. for Biodiesel Production', in 2019 International Conference on Power Generation Systems and Renewable Energy Technologies (PGSRET). IEEE, pp. 1-6.

Johnson, L. and Lusas, E. W. (1983) 'Comparison of alternative solvents for oils extraction', Journal of the American Oil Chemists' Society. Wiley Online Library, 60(2Part1), pp. 229-242.

Kim, M.-K. et al. (1996) 'Seasonal variations of triacylglycerols and fatty acids in Fucus serratus', Phytochemistry. Elsevier, 43(1), pp. 49-55.

Leite, G. B., Abdelaziz, A. E. M. and Hallenbeck, P. C. (2013) 'Algal biofuels: challenges and opportunities', Bioresource technology. Elsevier, 145, pp. 134-141.

Ma, F. and Hanna, M. A. (1999) 'Biodiesel production: a review', Bioresource technology. Elsevier, 70(1), pp. 1-15.

Marycz, K. et al. (2017) 'The cladophora glomerata enriched by biosorption process in Cr(III) improves viability, and reduces oxidative stress and apoptosis in equine metabolic syndrome derived adipose mesenchymal stromal stem cells (ASCs) and their extracellular vesicles (MV's)', Marine Drugs, 15(12), pp. 1-18. doi: 10.3390/md15120385.

Mercer, P. and Armenta, R. E. (2011) 'Developments in oil extraction from microalgae', European journal of lipid science and technology. Wiley Online Library, 113(5), pp. 539-547.

Murugesan, A., Umarani, C., Subramanian, R., et al. (2009) 'Bio-diesel as an alternative fuel for diesel engines - a review', Renewable and sustainable energy reviews. Elsevier, 13(3), pp. $653-662$.

Murugesan, A., Umarani, C., Chinnusamy, T. R., et al. (2009) 'Production and analysis of biodiesel from non-edible oils - a review', Renewable and Sustainable Energy Reviews. Elsevier, 13(4), pp. 825-834.

Nafis, G. A. et al. (2015) 'Combination pulsed electric field with ethanol solvent for Nannochloropsis sp. extraction', in AIP Conference Proceedings. AIP Publishing LLC, p. 30021. 
Nelson, G. J. (1993) 'Isolation and purification of lipids from biological matrices', Analyses of fats, oils and derivatives. AOCS Press, Champaign, pp. 20-89.

Pandey, A. et al. (2018) Biomass, biofuels, biochemicals: biofuels from algae. Elsevier.

Pradana, Y. S. et al. (2017a) 'Oil Algae Extraction of Selected Microalgae Species Grown in Monoculture and Mixed Cultures for Biodiesel Production', Energy Procedia. The Author(s), 105, pp. 277-282. doi: 10.1016/j.egypro.2017.03.314.

Pradana, Y. S. et al. (2017b) 'Oil Algae Extraction of Selected Microalgae Species Grown in Monoculture and Mixed Cultures for Biodiesel Production', Energy Procedia. The Author(s), 105, pp. 277-282. doi: 10.1016/j.egypro.2017.03.314.

Probst, K. V et al. (2017) 'Evaluation of green solvents: Oil extraction from oleaginous yeast Lipomyces starkeyi using cyclopentyl methyl ether (CPME)', Biotechnology Progress. Wiley Online Library, 33(4), pp. 1096-1103.

Shahzad, I. et al. (2010) 'Algae as an alternative and renewable resource for biofuel production', The boil (Ejournal for life scinces), 1(1), pp. 16-32.

El Sikaily, A. et al. (2006) 'Removal of methylene blue from aqueous solution by marine green alga Ulva lactuca', Chemistry and Ecology. Taylor \& Francis, 22(2), pp. 149-157.

Soxhlet, F. (1879) 'Die gewichtsanalytische bestimmung des milchfettes', Polytechnisches J, 232, pp. 461-465.

Sun, A. et al. (2011) 'Comparative cost analysis of algal oil production for biofuels', Energy. Elsevier, 36(8), pp. 5169-5179. 